\section{The House Mouse}

\section{And Murine Typhus \\ In Mississippi}

\author{
By William W. Smith, Ph.D.
}

$\mathrm{M}$ URINE TYPHUS, a rickettsial disease endemic in Mississippi as well as the other southeastern States, was first noted by the Mississippi State Board of Health in 1917 when 9 cases were reported from the delta counties. There is some doubt as to the authenticity of these cases, and no others were reported until 1933. With the exception of 2 years, the number of human cases rose annually from that date until a peak of 235 cases was reached in 1945 . Annual rat poisoning campaigns and ratproofing measures conducted by many cities of the State reduced economic damage but were not successful in preventing a continuous annual increase in cases reported. When DDT became available for use by the Public Health Service and the State health departments in 1945, it gave promise of genuine control of this disease by controlling the chief arthropod vector, the oriental rat flea (Xenopsyllacheopis), when applied as a dust to the runways, nests, burrows, and other habitats of domestic rats (Rattus norvegicus, Rattus rattus alexamdrinus).

\section{Previous Control and Survey Work}

Cooperative DDT dusting campaigns were initiated by the Mississippi State Board of

Dr. Smith, a medical entomologist with the Public Health Service since 1943, is presently assigned to the Communicable Disease Center Technology Branch, Newton Field Station Unit in Georgia. This paper is adapted from a thesis.presented to the Tulane University of Louisiana in partial fulfillment of the requirements for the degree of doctor of philosophy.
Health and the Public Health Service in 1945, and the decline in the number of murine typhus fever cases after that date is believed due chiefly to these campaigns. Periodic rat-trapping, collecting, and testing of rat blood serums for the presence of murine typhus antibodies and collection and identification of rat ectoparasites constituted an integral part of these typhus control programs. The murine typhus fever cases reported in Mississippi during the period 193349 follow:

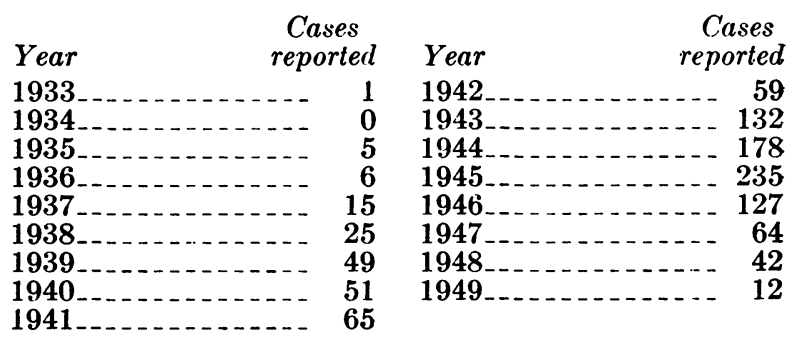

The information obtained served to locate murine typhus foci in the State. A survey conducted in 1946 and 1947 showed that the disease was confined chiefly to the part of the State south of Jackson and revealed the towns and counties where most emphasis should be placed on typhus control work. By 1949 few typhus foci could be shown among rats anywhere in the State, and intensified poisoning attempts had greatly reduced rat populations. However, these efforts had reen directed at the control of domestic rats and apparently had left house mouse populations intact. Often house mice increased as rat populations were reduced, probably because of lessened competition for available food. differences in control measures required, and other factors.

\section{Aims and Objectives}

It seemed desirable to determine the importance of the house mouse as a possible reservoir of murine typhus and the importance of its ectoparasites as compared with the ectoparasites of the domestic rats. The house mouse is at least as widespread in distribution as is the domestic rat and is even more intimately associated with man in the regions where murine typhus is found. 
House mouse survey in Mississippi, July 1, 1949, to June 30, 1950.

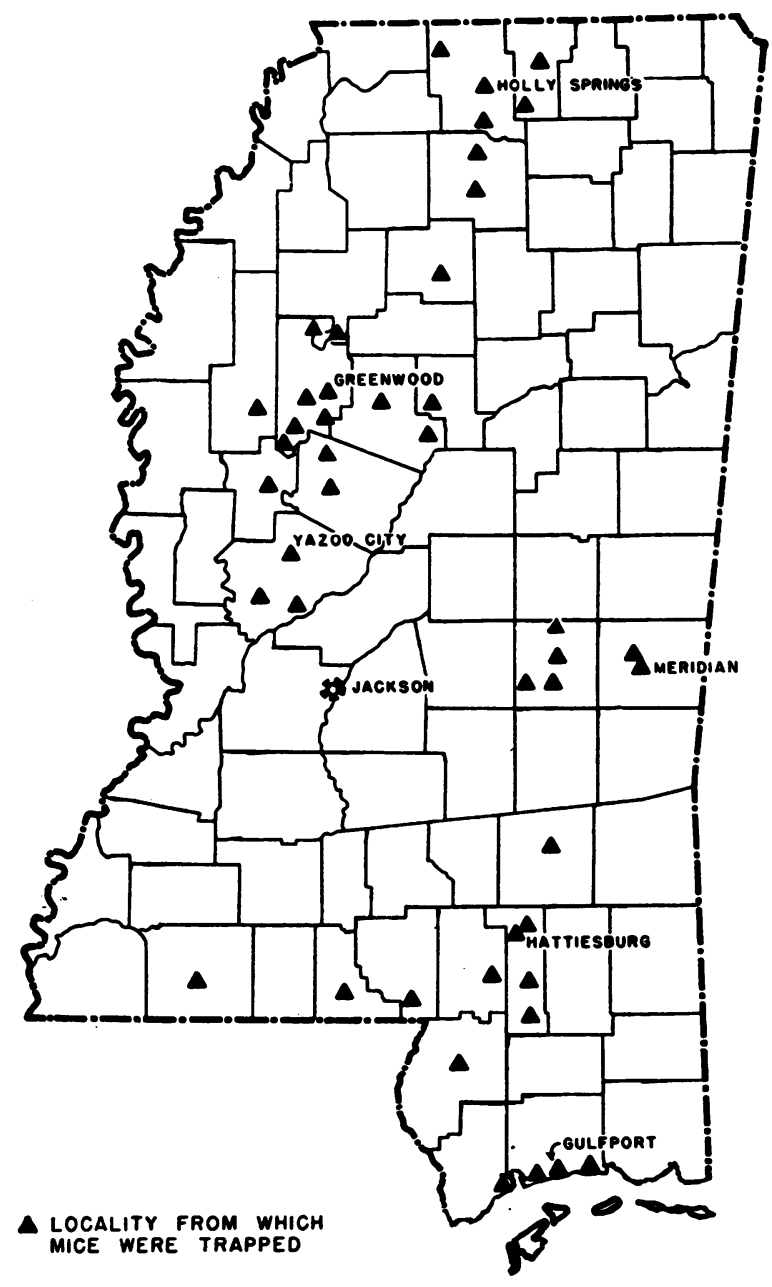

\section{Methods}

A house mouse survey of 1 year's duration (July 1, 1949, to June 30, 1950) was planned cooperatively by the sanitary engineering division of the Mississippi State Board of Health and the Public Health Service as a part of the typhus control program.

House mice were trapped from six regions of the State. The headquarters for these regions from north to south in the State were located as follows: north central, Holly Springs; northwest central, Greenwood; west central, Yazoo City; east central, Meridian; south central, Hattiesburg; southeast coastal, Gulfport (map). With regard to isothermal zones, the north central, northwest central, and east central regions are within the $60^{\circ}$ to $65^{\circ} \mathrm{F}$. zone, while the south central and the southeast coastal regions are in the $65^{\circ}$ to $70^{\circ} \mathrm{F}$. zone. The west central region lies on the boundary between the two zones. Very few human typhus cases have occurred in the more northern temperature zone of the State.

Trapping was conducted in four types of indoor habitats classified as "food-handling establishments," "other business establishments," "farms," and "residences." These were chosen as inclusive of most situations in which mice were in close association with man. No mice were trapped outdoors, but at the approach of cooler weather in the fall mice were observed to appear in residences from which they had been absent during the summer.

Live traps of the type used in a rickettsialpox survey in New York (1) were utilized. Ten to 15 traps were set per station during the late afternoon, usually on 1 day of each week. They were collected early the following morning, and the mice were taken to the laboratory in the traps. Each mouse in turn was anesthetized and killed by bleeding from the heart. Blood obtained from several specimens from the same habitat was pooled (range 1-5 mice per pool, average 3.4 mice per pool) to supply sufficient serum for testing after centrifuging. Serums were collected in sterile vials in which merthiolate crystals had been deposited for bacteriostatic effect. The vials were mailed to the Public Health Service Communicable Disease Center Laboratory at Chamblee, Ga., where the serums were tested for the presence of murine typhus antibodies.

\section{Survey Findings and Discussion}

Bloods from 995 mice composed the 294 serum pools successfully tested. Only 1 serum pool was found positive for the antibodies of murine typhus (see table). The positive pool was obtained from two mice trapped in a barn near Sandy Hook (Marion County) in the south central region. This particular barn had harbored typhus-infected rats for several years. 
Results of complement fixation tests of pooled house mouse blood serums for typhus fever in Mississippi, by months

\begin{tabular}{|c|c|c|c|c|}
\hline Year and month & Positive & Negative & $\begin{array}{l}\text { Unsatis- } \\
\text { factory }\end{array}$ & Total \\
\hline 1949 & & & & \\
\hline $\begin{array}{l}\text { July } \\
\text { August } \\
\text { September. } \\
\text { October } \\
\text { November } \\
\text { December }\end{array}$ & $\begin{array}{l}0 \\
0 \\
0 \\
1 \\
0 \\
0\end{array}$ & $\begin{array}{r}7 \\
8 \\
33 \\
19 \\
17 \\
16\end{array}$ & $\begin{array}{r}2 \\
17 \\
21 \\
23 \\
13 \\
6\end{array}$ & $\begin{array}{r}9 \\
25 \\
54 \\
43 \\
30 \\
22\end{array}$ \\
\hline 1950 & & & & \\
\hline $\begin{array}{l}\text { January } \\
\text { February } \\
\text { March } \\
\text { April } \\
\text { May } \\
\text { June }\end{array}$ & $\begin{array}{l}0 \\
0 \\
0 \\
0 \\
0 \\
0 \\
0\end{array}$ & $\begin{array}{l}13 \\
34 \\
39 \\
43 \\
48 \\
16\end{array}$ & $\begin{array}{r}14 \\
3 \\
4 \\
7 \\
11 \\
12\end{array}$ & $\begin{array}{l}27 \\
37 \\
43 \\
50 \\
59 \\
28\end{array}$ \\
\hline Total & 1 & 293 & 133 & 427 \\
\hline
\end{tabular}

The low titer of the serum, 1:8, is believed to reflect the last remnant of the typhus infection in rodents at this location. Attempts were made to obtain mice from all the premises known to harbor rats with positive titers, but it was possible to obtain samples from only 7 of 13 such premises. Usually the number of mice obtained was small, and positive mice may have been missed. However, 1 positive serum from the 7 premises known to have had positive rats recently is of considerable significance. These findings suggest that where ranges of house mice and domestic rats overlap, some of the mice are likely to be infected if the rats are typhus-positive.

The percentage found positive here $(0.34$ percent) is low compared with percentages of house mice found positive elsewhere by other workers (2-4). In this instance it should be remembered that in Mississippi mice which actually had a chance for exposure to infected rat ectoparasites were trapped from premises where intensive DDT dusting had been conducted annually for several years.

It was concluded that the house mouse is of little importance as a reservoir of murine ty- phus in Mississippi at present and that it is of possible importance only where its range overlaps that of infected domestic rats.

\section{Summary}

Mississippi is one of the southeastern States in which murine typhus is endemic. A peak of human cases (235) was reported in 1945-the disease had been present and had increased since 1933. The great decrease in the number of cases since 1945 is believed due chiefly to the DDT dusting campaigns conducted by the Mississippi State Board of Health, the Public Health Service, and the cities and counties in the southern part of the State. The wide distribution of the house mouse and its close association with man suggested the desirability of evaluating its importance as a reservoir of murine typhus. A survey in which 294 pools of blood serums from 995 house mice were obtained showed only 1 positive for the antibodies of murine typhus. The positive pool was obtained from serums of 2 mice taken from a barn known to have harbored typhus-positive domestic rats recently. It was the only positive serum of 7 pools taken from such infected premises and could indicate that the house mouse is more likely to be infected where its range is overlapped by that of infected domestic rats. The importance of the house mouse in the epidemiology of murine typhus in Mississippi appears to be negligible at present.

\section{REFERENCES}

(1) Horn, M. B. : Rickettsialpox survey in New York City. CDC Bull., April-May-June 1949, pp. 38-39.

(2) Morlan, H. B., Hill E. L., and Schubert, J. H.: Serological survey for murine typhus infections in southwest Georgia animals. Pub. Health Rep. 65: 57-63 (1950).

(3) Beck, D. M., and van Allen, A.: Typhus fever in California, 1916-1948, inclusive. San Francisco, California State Department of Public Health, 1951. pp. 20-30.

(4) Keaton, R., Nash, B. J., Murphy, J. N., and Irons, J. V.: Complement fixation tests for murine typhus on small mammals. Pub. Health Rep. 68 : 28-29 (1953). 